\title{
Intrapartum Management of Glucose for Diabetes in Pregnancy
}

\author{
Sulaiman Haji Ali ${ }^{1}$, Recie Davern ${ }^{1}$ and Mensud Hatunic ${ }^{1,2 *}$ \\ ${ }^{1}$ Department of Endocrinology, Mater Misericordiae University Hospital, Ireland \\ ${ }^{2}$ School of Medicine, University College Dublin, Ireland
}

Submission: October 21, 2019 , Published: October 29, 2019

*Corresponding author: Mensud Hatunic, Department of Endocrinology, Mater Misericordiae University Hospital, Ireland

\begin{abstract}
Diabetes mellitus (DM) in pregnancy can be classified into either pre-existing diabetes or gestational diabetes mellitus (GDM) [1]. Gestational diabetes is defined as glucose intolerance with onset or first recognition during pregnancy [2]. Several adverse outcomes have been associated with diabetes during pregnancy and controlling blood glucose during pregnancy minimizes the risk of complications.

Furthermore, intrapartum glycaemic control is important for the foetus as factors such as foetal academia and hypoglycaemia are strongly related to maternal hyperglycaemia during labour. There is no clear recommendation regarding target blood glucose during labour. The National Maternity Hospital (NMH) is a tertiary level unit in Dublin, with more than 9000 births per year. A weekly multidisciplinary clinic is provided by endocrinologists, obstetricians, midwife diabetes specialists and dietitians. In this article we share our experience in the management of blood glucose during labour for patients attending the NMH with five different cases. These cases involve the spectrum of diabetes in pregnancy which include: Type 1 DM treated with insulin pump, Type 1DM on subcutaneous (SC) insulin, Type 2DM treated with subcutaneous insulin, GDM treated with Metformin and GDM treated with SC insulin. A specific labour protocol was used for each of the above patients which we believe contributed to good maternal and foetal outcomes and good blood glucose control.
\end{abstract}

Keywords: Pregnancy; Diabetes; Insulin labour management

\section{Cases}

\section{Case 1}

33 year old female para $1+0$ with a history of gestational diabetes during her first pregnancy controlled with diet only with no complications. GDM was diagnosed at 21 weeks of gestation and treated with diet initially. At 22 weeks of gestation she required metformin 500mg twice daily and was under regular follow up in the maternity multidisciplinary diabetes clinic. Our patient had excellent blood glucose control until the end of pregnancy with a $\mathrm{HbA} 1 \mathrm{c}$ of $31 \mathrm{mmol} / \mathrm{mol}$ and a fructosamine level of 183-185.

$\mu \mathrm{mol} / \mathrm{L}$. Her foetal scan at 36 weeks showed polyhydramnios and foetal abdominal circumference $>95$ th centile. At 39 weeks of gestation she went into labour and was started on protocol 1 for blood glucose control. She was prescribed to receive 2 units of aspart (SC) if glucose $\geq 6 \mathrm{mmol} / \mathrm{L}$ and 3 units of aspart if

$\geq 8 \mathrm{mmol} / \mathrm{L}$. She underwent a normal vaginal delivery and her labour lasted 4 hours and 34 minutes. Her blood glucose readings during labour were $5.3,4.4$ and $5.6 \mathrm{mmol} / \mathrm{l}$. She had a healthy $3.8 \mathrm{~kg}$ baby boy with no neonatal hypoglycaemia. Post labour her blood glucose was checked only before meals for 48 hours and she was booked for an elective 2 hour $75 \mathrm{~g}$ oral glucose tolerance test in the 6-12 weeks post-delivery.

\section{Case 2}

2 year old female para 0 diagnosed with gestational diabetes at 23 weeks of gestation. Initially started on diet control for two weeks but her control was suboptimal. She was commenced on insulin in the form of aspart and insulatard with regular follow up in the multidisciplinary diabetes in pregnancy clinic. The insulin doses were escalated to reach the target blood glucose and the patient required up to 30 units of insulin daily in the third trimester of pregnancy. The patient showed excellent blood glucose control, mostly on target, and had a HbA1c of 35-37mmol/ mol and a fructosamine level of 187-189 $\mu \mathrm{mol} / \mathrm{L}$. Her foetal scan at 36 weeks of gestation was normal. At 37 weeks of gestation our patient went into labour and was started on protocol 2 for blood glucose control. She was prescribed one litre of Solution 18 with $20 \mathrm{mmol}$ potassium chloride and 5 units of actrapid at an infusion rate of $125 \mathrm{ml} / \mathrm{h}$. A supplementary SC sliding scale was also prescribed with 3 units of aspart if blood glucose $\geq 6 \mathrm{mmol} / \mathrm{L}$ 
and 4 units of aspart if $\geq 8 \mathrm{mmol} / \mathrm{L}$. She underwent normal vaginal delivery and her labour lasted 5 hours and 27 minutes. Her blood sugars during labour were 4.9, 5.5 and $4.4 \mathrm{mmol} / \mathrm{l}$. She had a healthy $2.6 \mathrm{~kg}$ baby girl with no neonatal hypoglycaemia. Her insulin was held post delivery and blood glucose before meals was monitored for 48 hours. She was booked for an elective 2-hour 75g oral glucose tolerance test 6-12 weeks post delivery.

\section{Case 3}

29 year old female para $1+0$ with a history of gestational diabetes during her first pregnancy and postpartum type 2 diabetes for 2 years duration. She was maintained on metformin $500 \mathrm{mg}$ twice daily with excellent control. She was evaluated by our team at the maternity diabetes clinic at 5 weeks of gestation, her initial $\mathrm{HbA} 1 \mathrm{c}$ was $44 \mathrm{mmol} / \mathrm{mol}$ and fructosamine level was $208 \mu \mathrm{mol} / \mathrm{L}$. Her blood glucose readings were above target and therefore her metformin was increased to $1000 \mathrm{mg}$ twice daily and she was started on insulin in the form of aspart and insulatard. She had regular follow up in the multidisciplinary diabetes in pregnancy clinic. The insulin doses were escalated to reach the target blood glucose and she required up to 47 units of insulin daily. Our patient showed excellent blood glucose control with the lowest $\mathrm{HbA} 1 \mathrm{c}$ being $34 \mathrm{mmol} / \mathrm{mol}$ and a fructosamine level of $187-194 \mu \mathrm{mol} / \mathrm{L}$. Her foetal scan at 37 weeks of gestation was normal. At 38 weeks of gestation she went into labour and was started on protocol 2 for blood glucose control. She was prescribed one litre of Solution 18 with $20 \mathrm{mmol}$ potassium chloride and 8 units of actrapid at an infusion rate of $125 \mathrm{ml} / \mathrm{h}$. A supplementary SC sliding scale was also prescribed with 3 units of aspart if blood glucose $\geq 6 \mathrm{mmol} / \mathrm{l}$ and 4 units of aspart if $\geq 8$ $\mathrm{mmol} / \mathrm{L}$. She was delivered by caesarean section which lasted 35 minutes with a blood sugar of $4.9 \mathrm{mmol} / \mathrm{l}$ one hour prior to surgery, $6.1 \mathrm{mmol} / \mathrm{l}$ during and $4.8 \mathrm{mmol} / \mathrm{l}$ post-delivery. She delivered a healthy $2.8 \mathrm{~kg}$ baby girl with no neonatal hypoglycaemia. Her insulin was stopped post delivery and her blood glucose was monitored for 48 hours. Her metformin dose was reduced to $500 \mathrm{mg}$ twice daily with a plan to follow her in a general diabetic clinic.

\section{Case 4}

35 year old female with a history of type 1 diabetes for 13 years duration. She was para 2 with two previous caesarean sections. She had uncontrolled diabetes pre pregnancy with a booking $\mathrm{HbA} 1 \mathrm{c}$ of $67 \mathrm{mmol} / \mathrm{L}$ and fructosamine level of $348 \mu \mathrm{mol} / \mathrm{L}$. Her pre-pregnancy diabetic regime was detemir 16 units daily and aspart 6 units with breakfast and lunch and 8 units with her evening meal. She was evaluated by our team at the maternity diabetes clinic at 5 weeks gestation and her insulin dose was adjusted according to her blood glucose readings on a regular basis. Her cetemir dose at its highest was 20 units per day and her aspart dose was escalated to a total of 48 units daily. This resulted in significant improvement in her diabetes control with her lowest $\mathrm{HbA} 1 \mathrm{c}$ being $47 \mathrm{mmol} / \mathrm{L}$ and her lowest fructosamine level being $241 \mu \mathrm{mol} / \mathrm{L}$. Her foetal scan at 37 weeks of gestation was normal. At 38 weeks of gestation she went into labour and was started on protocol 2 for blood glucose control. She was prescribed one litre of Solution 18 with $20 \mathrm{mmol}$ potassium chloride and 10 units of actrapid at an infusion rate of $125 \mathrm{ml} / \mathrm{h}$. A supplementary sliding scale was also prescribed with 3 units aspart if blood glucose was $\geq 6 \mathrm{mmol} / \mathrm{L}$ and 4 units of aspart if $\geq 8 \mathrm{mmol} / \mathrm{L}$. She delivered via caesarean section which lasted one hour with a blood glucose of $6.9 \mathrm{mmol} / \mathrm{l}$ prior to surgery, 6.2 and $6.9 \mathrm{mmol} / \mathrm{l}$ during and $7.2 \mathrm{mmol} / \mathrm{l}$ post-delivery. She had a healthy $3.9 \mathrm{~kg}$ baby boy with no neonatal hypoglycaemia. Her insulin was reduced post labour to detemir 15 units and aspart 5 units with each meal. It was arranged that she be followed in a general diabetes clinic post delivery.

\section{Case 5}

39 year old female with type 1 diabetes for 24 years. Her diabetes was complicated by proliferative diabetic retinopathy and nephropathy. Our patient was commenced on continuous subcutaneous insulin infusion (insulin pump) with aspart insulin three years ago due to frequent hypoglycaemic episodes. This was her first pregnancy, and she was seen in our maternity diabetes clinic at 4 weeks of gestation. She had three basal rates per day with a carbohydrate correction ratio with all meals and an insulin sensitivity factor of $1: 2$. The patient required an average of 30 units of insulin per day. Her initial HbA1c was $79 \mathrm{mmol} / \mathrm{L}$ and her fructosamine level was $325 \mu \mathrm{mol} / \mathrm{L}$. Her insulin dose was adjusted to reach the target for blood glucose control, requiring up to 5 basal rates of insulin and an average of 55 units of insulin per day. This improved her HbA1c to $41 \mathrm{mmol} / \mathrm{L}$ and her fructosamine level to $240 \mu \mathrm{mol} / \mathrm{L}$. Her foetal scan at 34 weeks of gestation showed an abdominal circumference $>95$ th percentile. At 38 weeks of gestation she went into labour and was started on protocol 3 for blood glucose control. She was prescribed one litre of solution 18 with $20 \mathrm{mmol}$ potassium chloride at an infusion rate of $125 \mathrm{ml} / \mathrm{h}$ and an insulin pump rate of 0.5 units/hour. A supplementary sliding scale was also prescribed with 3 units aspart if blood glucose $\geq 6 \mathrm{mmol} / \mathrm{L}$ and 4 units of aspart if $\geq 8 \mathrm{mmol} / \mathrm{L}$. She delivered via caesarean section which lasted 40 minutes with a blood glucose of $4.4 \mathrm{mmol} / \mathrm{l}$ prior to surgery, $6.2 \mathrm{mmol} / \mathrm{l}$ during and $7.8 \mathrm{mmol} / \mathrm{l}$ post-delivery. She had a healthy $3.8 \mathrm{~kg}$ baby girl with no neonatal hypoglycaemia. Her insulin was reduced post labour with regular follow up in a diabetic clinic.

\section{Discussion}

Diabetes mellitus (DM) in pregnancy can be categorized into either pre-existing diabetes or gestational diabetes mellitus (GDM) [1]. In both categories there is a higher risk of complication to the mother and the foetus. Preeclampsia, macrosomia, maternal and infant birth trauma, fatal hepatomegaly or cardiomegaly, operative delivery, perinatal mortality amongst others are all complications of hyperglycaemia during pregnancy [3]. Management of diabetes during pregnancy depends on the type and severity of diabetes. Pregnant women with pre-existing type 1DM can either be treated with subcutaneous insulin or contin- 
ues subcutaneous insulin infusion (CSII). Those with pre-existing Type 2DM can either be managed with insulin, oral hypoglycaemic agents or diet. GDM can also be managed with diet alone, oral hypoglycaemic agents and/or insulin. The main goal with any management plan is to achieve normoglycemia and to prevent maternal and foetal complications.

The occurrence of foetal acidaemia and hypoglycaemia is strongly associated with maternal hyperglycaemia during labour due to foetal hyperinsulinemia [4]. The reduced calorie intake and cessation of oral intake during the latent phase of labour and the higher energy requirement during the active phase of labour are both implicated in the lower insulin requirement during labour. Fluid solutions containing dextrose can also be important for optimal myometrial function during labour [5,6].

Table 1: Recommendation of Blood glucose target during labor with different guidelines.

\begin{tabular}{|c|c|}
\hline $\begin{array}{c}\text { The American College of Obstetri- } \\
\text { cians and Gynecologists [8] }\end{array}$ & $\begin{array}{c}>3.9 \text { and }<7 \mathrm{mmol} / \mathrm{L} \text { ( }>70 \text { and } \\
<126 \mathrm{mg} / \mathrm{dL})\end{array}$ \\
\hline $\begin{array}{c}\text { The Endocrine Society Clinical } \\
\text { Practice Guidelines [9] }\end{array}$ & $\begin{array}{c}>3.9 \text { and }<7 \mathrm{mmol} / \mathrm{L}(>70 \text { and } \\
<126 \mathrm{mg} / \mathrm{dL})\end{array}$ \\
\hline NICE guidelines [10] & $4-7 \mathrm{mmol} / \mathrm{L}$ \\
\hline $\begin{array}{c}\text { Canadian Diabetes Association } \\
\text { (CDA) }\end{array}$ & $4-7 \mathrm{mmol} / \mathrm{L}$ \\
\hline $\begin{array}{c}\text { International Federation of Gyne- } \\
\text { cology and Obstetrics (FIGO) [11] }\end{array}$ & $4-7 \mathrm{mmol} / \mathrm{L}$ \\
\hline
\end{tabular}

The metabolic changes during labour require close glucose level monitoring. However, the ideal blood glucose target during labour to prevent foetal complications is still unclear. The frequency of monitoring of blood glucose during the intrapartum period depends on the phase of labour. It is recommended to monitor capillary blood glucose 2-4 hourly during the latent phase of labour and 1-2 hourly during the active phase to achieve good glycaemic control [4]. Several guidelines and recommendations for target blood glucose have been summarised in Table 1. It's important to note that a maternal blood glucose value of more than $10 \mathrm{mmol} / \mathrm{L}(180 \mathrm{mg} / \mathrm{dl})$ during labour has been proven to be associated with a high risk of neonatal hypoglycaemia [7].

The diabetic management plan during labour should be individualized for each woman due to the differences in the type and severity of diabetes, beta cell reserve and the severity of insulin resistance. Unfortunately, a recommendation of optimal approach to achieve normoglycemia intrapartum does not exist due to the lack of well-designed, sufficiently powered, randomized trials. Here we share our experience of managing blood glucose levels during labour using fixed protocols. These protocols are individualized according to the type of diabetes during pregnancy, pre-delivery diabetic management and blood glucose control [8-11].

\section{Compliance with Ethical Standards}
a) This paper was not funded
b) Author Sulaiman Haji Ali declares that he has no con- flict of interest

c) Author Recie Davern declares that she has no conflict of interest

d) Author Mensud Hatunic declares that he has no conflict of interest

e) Ethical approval: This article does not contain any studies with human participants or animals performed by any of the authors

f) Informed consent was obtained from all individual participants included in the study (Protocol 1-3).

\section{References}

1. Magon N (2011) Gestational diabetes mellitus: Get, set, go from diabetes capital of the world to diabetes care capital of the world. Indian J Endocrinol Metab 15(3): 161-169.

2. Mumtaz M (2000) Gestational diabetes mellitus. Malays J Med Sci 7(1): 4-9.

3. Dodd JM, Crowther CA, Antoniou G, Baghurst P, Robinson JS, et al. (2007) Screening for gestational diabetes: the effect of varying blood glucose definitions in the prediction of adverse maternal and infant health outcomes. Aust N Z J Obstet Gynaecol 47(4): 307-312.

4. Kalra P, Anakal M (2013) Peripartum management of diabetes. Indian J Endocrinol Metab 17(Suppl 1): S72-S76.

5. Jovanovic L (2004) Glucose and Insulin Requirements During Labor and Delivery: The Case for Normoglycemia In Pregnancies Complicated by Diabetes. Endocr Pract 10(Supplement 2): 40-45.

6. Shrivastava VK, Garite TJ, Jenkins SM, Saul L, Rumney P, et al. (2009) A randomized, double-blinded, controlled trial comparing parenteral normal saline with and without dextrose on the course of labor in nulliparas. Am J Obstet Gynecol 200(4): 379.e1-379.e6.

7. Carron Brown S, Kyne-Grzebalski D, Mwangi B, Taylor R (1999) Effect of management policy upon 120 Type 1 diabetic pregnancies: policy decisions in practice. Diabet Med 16(7): 573-578.

8. ACOG Committee on Practice Bulletins (2005) ACOG Practice Bulletin. Clinical Management Guidelines for Obstetrician-Gynecologists. Number 60, March 2005. Pregestational diabetes mellitus. Obstet Gynecol 105(3): 675-685.

9. Blumer I, Hadar E, Hadden DR, Jovanovič L, Mestman JH, et al. (2013) Diabetes and Pregnancy: An Endocrine Society Clinical Practice Guideline. J Clin Endocrinol Metab 98(11): 4227-4249.

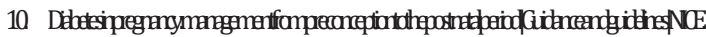

11. Hod M, Kapur A, Sacks DA, Hadar E, Agarwal M, et al. (2015) The International Federation of Gynecology and Obstetrics (FIGO) Initiative on gestational diabetes mellitus: A pragmatic guide for diagnosis, management, and care. Int J Gynecol Obstet 131(Suppl 3): S173-211. 

(CC) This work is licensed under Creative BY DOI: 10.19080/JGWH.2019.17.555955

\section{Your next submission with Juniper Publishers} will reach you the below assets

- Quality Editorial service

- Swift Peer Review

- Reprints availability

- E-prints Service

- Manuscript Podcast for convenient understanding

- Global attainment for your research

- Manuscript accessibility in different formats

( Pdf, E-pub, Full Tsext, Audio)

- Unceasing customer service

Track the below URL for one-step submission https://juniperpublishers.com/online-submission.php 